\title{
Teaching for democracy: Transformative learning theory mediating policy and practice
}

\author{
Janicke Heldal Stray og Emil Sætra
}

Faculty of religion and education, MF Norwegian School of Theology, Oslo

\begin{abstract}
The context of this article is the on-going renewal of the Norwegian curriculum. Our point of departure is the challenges that arise when implementing policy into practice. One of the traditional aspirations and goals of the Norwegian education system is to foster democratic citizens. How to implement democratic practices into the classroom is a challenge faced by politicians, academics as well as practitioners. One obstacle might be the lack of theoretical resources that can help translate policy in to practice. We argue that theory can be used for contextualising pedagogically grounded ethics on what goes on in the classroom. Theory can be used for translating policy into pedagogy. In this article, we propose transformative learning theory (TLT) as a possible resource for negotiating the gap between policy and practice.
\end{abstract}

Keywords: Democracy; citizenship; education; policy; transformative learning;

Received: September, 2016; Accepted: October, 2017; Published: December, 2017

\section{Introduction}

This paper examines democratic education ${ }^{1}$ in Norway. One of the traditional aspirations and goals of the Norwegian education system is to foster democratic citizens, which is stated in the Education Act as well as in the school curriculum goals of several school subjects. Both academics and practitioners have faced challenges regarding how to implement democratic practices in classroom teaching. Consequently, democratic education is an implicit mandate for teachers, and teaching for democratic

*Correspondence: Janicke Heldal Stray, MF Norwegian School of Theology, PB 5144 Majorstuen, 0302 Oslo. Email: janicke.h.stray@mf.no

${ }^{1}$ We use the terms democratic education, education for democracy, education for democratic citizenship and citizenship education interchangeably, depending on the context. 
citizenship is dependent on teachers' individual preferences and competencies. However, this situation may change as a result of a suggestion by the Ministry of Education to implement democracy and citizenship as one of three core priorities ${ }^{2}$ of the revised curriculum. One challenge facing the establishment of citizenship education as a core priority is the lack of an appropriate theoretical approach to democratic citizenship in the classroom. Theory can be used for contextualising pedagogically grounded ethics on what goes on in the classroom. In this article, we argue that theory can be used for translating policy into pedagogy and, we propose transformative learning theory (TLT) as a possible resource for negotiating the gap between policy and practice.

\section{Background}

Although interpretations of the 'good democratic citizen' will vary from one society to another, there is a general consensus that in a sound democracy, some core values must be transmitted to the next generation in order to enable the sustenance and development of democracy as a political means of governance and way of life. Democracy is, by definition, not a spectator sport. It demands active and engaged citizens in order to continue functioning as a political system. Norway's Education Act articulates several qualities that define the national conception of a 'democratic citizen'. Among the main tasks of the education system is fostering citizens who can communicate with others, understand other people's perspectives and think critically. Thus, the Education Act obliges schools to teach students about rights and responsibilities. Furthermore, students should learn participation skills, codetermination and develop a liberality ${ }^{3}$ or broadmindedness that will make them willing and able to respect and defend their rights as well as those of others.

As this is no easy task, the question of how to educate for democratic citizenship in accordance with the Education Act poses a major challenge for teachers and teacher educators. In 2015, the Ludvigsen Committee addressed these issues by mandating that students learn about democratic participation for democratic participation and through democratic participation (NOU, 2015, pp. 8, 30). The committee's recommendations are detailed in a White Paper discussing the reform of the curriculum (Meld.St.28, 2016). Moreover, the concept of democratic competence is highlighted and discussed in several paragraphs of the committee's paper (NOU, 2015 , pp. 8,30 ). The important aspects of democratic competence, according to the committee, include communicative, interactive and participatory competencies. The committee suggests that at its core, democratic competence is the competence to act, live and solve challenges in the community along with other community members. This entails possessing knowledge of important topics such as the political system and human rights (education about democracy). Furthermore, democratic

\footnotetext{
${ }^{2}$ The two others are sustainable development and health and life skills.
}

${ }^{3}$ Liberality can be translated into Norwegian as vidsyn. 
competence involves communication, such as being able to articulate opinions and to listen actively, and attitude, understood as respect for differences and listening to other opinions (education for democracy). The last dimension which the committee emphasises as vital for democratic competence is the ability to lead discussions, to allow everybody to be heard and to reach an agreement through compromise. The committee calls this 'action in practice', which can be understood as education through democracy.

Studies on how teachers implement democracy and citizenship in their teaching suggest that teachers are uncertain about how to interpret this mandate. They also report that these teachers experience having neither the time nor the training to anchor their teaching in the prospect of learning democracy (see, i.e. Stokkeland, 2016; Sætra, 2015). These findings support Stray's (2010) conclusion that democratic education is an implicit, not explicit, vision for Norwegian schooling. There might be several reasons for this situation, namely, teachers are not educated in terms of how to teach for democracy; the democratic mandate is not properly incorporated in the curriculum; there is insufficient time to explore and practice democracy in the classroom; and there is a lack of coherence between democratic theory and subject didactics. One additional explanation is that the dominant theoretical approaches to teaching for democracy in Norway is borrowed from researchers and political resolutions from other contexts, especially the British context. This is a consequence of the British influence on democracy in education, which follows Crick's (1998) report and the establishment of the master of citizenship programme in England (for one approach to the English interpretation see Arthur, Davison \& Stow, 2000). Lacking these kinds of initiatives, Norwegian researchers naturally looked to England as they sought to establish democracy and citizenship as a research field in Norway (e.g. Biseth 2014; Stray, 2011). Citizenship education is a controversial issue in England (Berger, 2012), which has a very different social and political structure compared to Norway. This is one of the main reasons why the English approach might not have been the most successful model for the Norwegian education system.

Moving to the national level, what we know about democratic citizenship education suggests that one of the main reasons why teacher educators and teachers in Norway face difficulty in implementing democratic education to a satisfactory degree in their educational practice has to do with the gap between policy, theory and practice. While Norwegian students are achieving high scores in international studies on democracy and willingness to participate (Mikkelsen, 2001; Fjeldstad, Lauglo \& Mikkelsen, 2010), research into these studies has been limited. For example, there is no way of determining whether a student's democratic competence is a consequence of schooling alone or whether the student is echoing the mainstream political attitudes from Norwegian media outlets and friends. This suggests that what is actually happening in the classroom with regard to democratic education remains unclear. We suggest that a stronger connection between theory and practice is possible, not only for guiding teachers' work in the classroom but also for exploring what actually takes place in the classroom. Furthermore, we suggest that this theoretical approach is 
suitable for different school subjects. Moreover, the need to interpret and translate policy into a theoretical approach that is relevant for practice is apparent. Before articulating how transformative learning theory can be applicable to democratic citizenship education, we shall discuss some key features and assumptions of democratic and citizenship education.

\section{Democratic and citizenship education}

At its core, citizenship education involves learning how to live together in a stable political community over time (Kymlicka \& Norman, 1995). In other words, citizenship education is about learning how to live in a democratic society as democratic citizens (Bîrzea, 2005, p. 24) and developing democratic identities. ${ }^{4}$ This implies that citizenship is not limited to a status that one inherits or receives as a citizen of a country. It also requires skills, values, attitudes and knowledge that must be acquired through learning. Regarding the learning process, it is not sufficient to learn about democracy - that is, rights and duties, government and politics. Students must also be prepared to serve as democratic citizens and develop a democratic identity. This process is characterised by the introduction of community values and attitudes. In addition, students must be able to practice democracy in school in order to serve as competent democratic citizens in their society (Stray, 2012). They need to develop knowledge, skills, values and attitudes that will enable them to take a critical stance towards social injustice, violations of rights, stereotypes and similar processes that are disruptive to the democratic process. In addition, students must be able to critically examine their own perceptions and assumptions.

There are several approaches to teaching democratic citizenship in Scandinavian schools, such as an emphasis on school subjects (Solhaug \& Børhaug, 2012), deliberation (Englund, 2015, 2016; Løvlie, 2006), multiculturalism (Andersen \& Biseth, 2013), cosmopolitism (Kemp, 2005) and Bildung (Korsgaard 2005), to mention some of the main contributions. One commonality among these contributions is that they involve discussions and theorisations from a Scandinavian point of view. Scandinavian education is politically influenced by a long tradition of social democracy (Thuen \& Vaage, 2004), which has been aimed at developing an education system that emphasises equity, social equality and social mobility. In addition, social philosophers like Rawls (Føllesdal, 2002, 2003), Dewey (Dale, 2005) and Habermas (Eriksen, 1995; Eriksen \& Weigård, 1999) have influenced Scandinavian countries. We suggest that transformative learning theory may be understood as embracing different approaches, as it uses deliberative theory (Habermas), democratic theory (Dewey) and emancipatory theory (Freire) as its foundation. In the next section, we

\footnotetext{
${ }^{4}$ Democratic identities can be understood as knowledge about, attitudes towards and values regarding a willingness and understanding of how to act democratically as situations require, also called preparedness or readiness for participation or taking action.
} 
shall present the theory, followed by a discussion of its relevance as a mediating tool between policy and practice.

\section{Transformative learning theory}

Transformative learning (TLT) was introduced almost 40 years ago by Jack Mezirow in relation to adult education. It is an emancipatory theory grounded in constructivism, humanism and critical theory, drawing on John Dewey, Jürgen Habermas, Paolo Freire, and Jerome Bruner, amongst others (Gravett, 2001; Mezirow, 1991). The core of the theory is learning, which leads to 'a deep shift in perspective, leading to more open, more permeable, and better-justified meaning perspectives' (Cranton \& Taylor, 2012, p. 3); hence it is transformative. The theory has been applied to research concerning 'individual change, organizational change, social change, and global change' (Cranton \& Taylor, 2012, p. 3). It is common for research and theoretical contributions to emphasise how meaning is created, validated and reformulated and how social conditions affect the ways in which people create meaning out of experience. According to Mezirow (1991, p. 10), to create meaning out of experience is the most prominent feature of human beings and that it is crucial to be able to act effectively. 'Only when things about us have meaning for us, only when they signify consequences that can be reached by using them in certain ways, is any such thing as intentional, deliberate control of them possible' (Dewey as cited in Mezirow, 1991, p. 4). Thus, meaning is understood as interpretation: creating meaning is about making interpretations of experiences in ways that put them into context (Mezirow, 1991, p. 4).

A key concept of TLT is what Mezirow calls habits of expectations or meaning perspectives. Meaning perspectives, or generalised sets of habitual expectations, 'act as perceptual and conceptual codes to form, limit, and distort how we think, believe, and feel and how, what, when, and why we learn' (Mezirow, 1991, p. 34). Habits of expectations filter both perception and understanding. Humans internalise definitions, assumptions and typologies that have been communicated to them through socialisation. In making meaning out of experience, we all start from and operate within, the horizon of understanding that we have constructed and established the basis of prior experience. Consequently, becoming an autonomous individual requires that what has been given to us through tradition, culture and socialisation is made conscious for us (Mezirow, 1991, pp. 1-2). Freedom and emancipation are about being able to articulate our own reality, 'to speak with our own voice' (Mezirow, 1991, p. 3). Furthermore, a concept closely related to that of meaning perspectives is meaning schemes. These entail 'specific knowledge, beliefs, value judgements, and feelings that constitute interpretations of experience' (Mezirow, 1991, pp. 5-6). While meaning perspectives signify groups of related meaning schemes, meaning schemes function as specific habits of expectations (Mezirow, 1991, p. 35). 
Central to TLT is the assumption that meaning perspectives are acquired more or less uncritically (and therefore without consciousness) through socialisation, resulting in limitations and distorted perceptions and an understanding of the world around us. This can be challenged and transcended through critical reflection. Another key part of TLT concerns how we support and validate communicated ideas and what we have learnt from past interactions. It is in this communicative process that our meaning perspectives are put into play, challenged and transcended. When we reflect on content or process, meaning perspectives can be sustained, expanded or transformed. Reflection on basic assumptions about the world can lead to the transformation of both meaning perspectives and the experience that is being interpreted (Mezirow, 1991, pp. 5-6). Mezirow (1991, p. 104) distinguishes between three different forms of reflection, understanding it as 'a process of critically assessing the content, process, or premise(s) of our efforts to interpret and give meaning to an experience'.

This way of understanding experience and meaning perspectives has implications for the interpretation of learning and the learning process. Framed in TLT, this interpretation can be understood as:

the extension of our ability to make explicit, schematize (make an association within a frame of reference), appropriate (accept an interpretation as our own), remember (call upon an earlier interpretation), validate (establish the truth, justification, appropriateness, or authenticity of what is asserted), and act upon (decide, change an attitude toward, modify a perspective on, or perform) some aspect of our engagement with the environment, other people, or ourselves. (Mezirow, 1991, p. 11)

Thus, learning can be defined as 'a process of using a prior interpretation to construe a new or a revised interpretation of the meaning of one's experience in order to guide future action' (Mezirow, 1991, p. 12). Mezirow uses the term action quite broadly, which entails different forms of action, such as 'making a decision, making associations, revising a point of view, reframing or solving a problem, modifying an attitude, or producing a change in behaviour' (Mezirow, 1991, p. 12). Action is related to what he calls praxis - a form of creative implementation of a purpose. Transformative learning is the process by which learners transform their 'taken for granted frames of reference (meaning perspectives, habits of mind, mind sets) to make them more inclusive, discriminating, open, emotionally capable of change, and reflective so that they may generate beliefs and opinions that will prove more true or justified to guide action' (Mezirow, 2000, p. 7)

According to Mezirow, learning takes place in five interrelated contexts: (1) the frame of reference or meaning perspective in which the learning is embedded; (2) the conditions of communication, such as 'language mastery, the codes that delimit categories, constructs, and labels; and the ways in which problematic assertions are validated'; (3) 'the line of action in which learning occurs'; (4) 'the self-image of the learner' and (5) 'the situation encountered, that is, the external circumstances within which an interpretation is made and remembered' (Mezirow, 1991, pp. 13-14). It is important 
to note that Mezirow emphasises the line of action within which the learning process occurs as this influences perception, memory, problem solving and learning.

\section{Three forms of learning}

Mezirow (1991, p. 64) makes an analytic distinction between three forms of learning: instrumental learning, communicative learning and emancipatory learning. Each domain is 'knowledge constitutive'; in other words, each has its 'own distinctive categories for interpreting experience, methods for discovering knowledge, and methods for validating assertions pertaining to it' (Mezirow, 1991, p. 72). The categories are based on Habermas' theory of communicative action. Instrumental learning and communicative learning are understood as distinct domains of learning, while the emancipatory dimension of learning bears implications for the two former categories. However, as Mezirow (1991, p. 80) stresses, the distinction between instrumental and communicative learning does not signify a dichotomy. Indeed, most learning entails both instrumental and communicative aspects.

The distinction between instrumental and communicative learning is centred on the dynamics of learning. While instrumental learning is about learning how to control the environment, communicative learning entails learning to understand others. In turn, this difference calls for different methods of enquiry (Mezirow, 1991, p. 73). Instrumental action concerns predictions about observable events, which can be proven right or wrong by means of evidence. The purpose of instrumental learning is to establish cause-effect relationships through task-oriented problem solving (Mezirow, 1991, p. 73).

Communicative learning is essentially about understanding what is learned and making oneself understood by others. This process entails 'understanding, describing, and explaining intensions; values; ideals; moral issues; social, political, philosophical, psychological, or educational concepts; feelings and reasons' (Mezirow, 1991, p. 75). Thus, communicative action involves a distinctly different way of constituting knowledge of what communicative action achieves. The domain is regulated by norms grounded in mutual consent; these, in turn, define mutual expectations. Further, the validity of social norms is grounded in inter-subjectivity a mutual understanding of intentions - and 'secured by the general recognition of obligations' (Mezirow, 1991, p. 75). When we want to decide what is 'right or wrong, bad or good, correct or incorrect, appropriate or inappropriate, beautiful or ugly' within this domain, it cannot be done through the kind of empirical-analytical enquiry as within the domain of instrumental learning. Within the domain of communicative learning, validity testing happens by trying to reach agreement through rational discourse (Mezirow, 1991, p. 76), or according to Habermas, deliberation. In other words, the purpose of communicative learning is not to locate relationships of cause and effect but to gain insight and find common ground through communication (Mezirow, 1991, p. 80). 
Emancipatory learning is about challenging distorted meaning perspectives through reflection. Moreover, emancipatory knowledge is constituted on the basis of self-reflection. In other words, one gains this kind of knowledge through the process of critical self-reflection, which is different from technical interest in the environment or practical interest in social connections. Emancipatory learning leads to liberation from forces that limit our opportunities to take control over our own lives. Examples of such forces are 'misconceptions, ideologies, and psychological distortions in prior learning that produce or perpetuate unexamined relations of dependence' (Mezirow, 1991, p. 87). When self-reflection is critical, it entails a critical examination of once taken-for-granted perceptions. Thus, emancipatory learning is often transformative as the learner is made aware of new and alternative ways of interpreting experiences. When learning is emancipatory, it might also contribute to the development of an increased and more inclusive understanding of the world, enabling the learner to integrate new experiences in qualitatively better ways (Mezirow, 1991, p. 88). As a final remark, it is important to stress that both the instrumental and communicative aspects of learning are part of most actions and learning about the world, other people and ourselves. In other words, learning is multidimensional; it entails 'learning to control the environment, to understand meaning as we communicate with others, and to understand ourselves' (Mezirow, 1991, p. 89).

\section{Transformative learning and identity}

A critical interpreter of Mezirow, Knud Illeris (2014), relates TLT to the concept of identity. As Illeris (2014, p. 124) points out, TLT is scarcely used or related to any context outside of higher education in Western countries, although there is nothing in the concept itself to indicate that it must be limited to higher education. Indeed, TLT concerns all learning that involves changes in meaning perspectives and frames of reference and, as suggested by Illeris, changes in the identity of the learner. Illeris (2014, p. 86) argues that the term 'youth' is used relatively loosely and that both the psychological and common understandings suggest that 'youth' begins in early puberty (11-13 years old) and lasts until a relatively stable identity is established, typically in the mid- to- late twenties. In particular, ages 16 through 19 characterise an important and intense period of identity development in addition to being important years of public schooling (Illeris, 2014, p. 126). Therefore, TLT is relevant for theorising about and understanding how students develop democratic identities. According to Illeris, however, this way of thinking about education is far removed from hegemonic views on the scope of education. Rather, it is the government that decides what kind of knowledge and skills are to be understood as relevant to the lives of young people (Illeris, 2014, p. 126). In what follows, we argue that the scope of education for democratic citizenship, understood in a broad sense as 'learning to live together in a stable political community', communicates very well with the 
principles of TLT and the development of a democratic identity. In the next section, we contextualise this discussion using some of the proposals from the Ludvigsen Committee and the White Paper on reforming the Norwegian curriculum (Meld. St.28, 2016).

\section{Developing democratic identities through transformative learning}

To contribute to the pedagogical field of teaching and learning democratic citizenship, it is of crucial importance that we move beyond the theoretical towards practice. It is also important to elaborate on how policy can be translated into reality - in other words, develop theoretical tools for implementing policy in praxis. In this section, we discuss the Ludvigsen committee's recommendations in the framing of TLT and democratic citizenship.

The key concept in NOU, 2015:8 is competence. The committee emphasises four different areas of competence: (1) subject-specific competence, (2) competence in learning, (3) communicative, interactive and participatory competence and (4) explorative and creative competence. As the purpose of this contribution extends across the curriculum, we emphasise the last two forms of competence - communicative, interactive and participatory competence and explorative and creative competence.

The committee emphasises that competence is not limited to knowledge and skills, that it is also about how students make use of these, 'being able to reflect on and consider what a situation or task demands, what is ethically justifiable and what the consequences of an action are' (NOU, 2015:8, p. 18, our translation). Competence as a key concept must reflect the diversity and complexity of the tasks in education. In the report, competence is defined as:

being able to master challenges and solve tasks in different contexts; it entails cognitive, practical, social and emotional learning, and development, including attitudes, values, and ethical judgements. Competence can be developed and learned and is expressed through what persons do in different activities and situations. (NOU, 2015:8, p. 19)

This broad approach to competence - including attitudes, values and ethical judgements - constitutes a clear foundation of the committee's emphasis on democratic and citizenship education. Indeed, the justification for stressing the communicative, interactive and participatory form of competence is that it will be important to the schools of the future, that communication and interaction should be understood as interlocking competencies and that interaction and democracy are needed locally, nationally and globally (NOU, 2015:8, p. 27). Furthermore, the committee explicitly relates this area of competence to what it calls democratic competence:

1. As mentioned earlier, the committee suggests that democratic competence is about knowledge of 'the political system, human rights, and being able to participate in elections and other democratic decision-making procedures'; 
2. values that are important for democratic participation, such as 'being able to articulate opinions, participate in discussions, listen to and show respect for other points of view';

3. and instruction through democratic participation, understood as 'democratic actions in practice, such as being able to lead discussions, let everyone be heard, and be able to come to an agreement and make compromises' (NOU, 2015:8, our translation).

In the following section, we discuss how such competence can be developed in practice.

\section{Communicative, interactive and participatory competence}

Communication, interaction, and participation are dialogical $l^{5}$ concepts whereby the persons involved need to talk to each other on some level. In TLT, dialogue refers to a mutual and respectful relationship between the teacher and the student whereby the teacher and the student think and reason together. In other words, dialogical teaching presupposes that the teacher does not function as a unilateral authority. This, however, does not mean that the teacher does not have an authoritative role in the dialogue. On the contrary, based on the content and situation, the teacher can facilitate the student's learning in a number of ways, including through 'lectures and summaries of subject matter, comments on learners' contribution, discussion of learners questions, narrative demonstrations of procedures and so forth' (Gravett, 2001, p. 37). In line with TLT in general, Gravett (2001) suggests that dialogue should not be understood as 'neither content-, learner-, nor teacher-centered, but learning-centered' (Gravett, 2001, p. 36). Learning tasks mark the central point of instruction and function as a mediating tool that structures the dialogue between the teacher and the students (Gravett, 2001, p. 57). Both the content of learning and the actions that students must take in order to learn are included in the task itself. With the help of learning tasks, the students are made to interact with the subject content immediately (Gravett, 2001, p. 58). In this view, learning tasks are in line with the recommendations of the Ludvigsen Committee (NOU, 2015:8) regarding the idea that students must do something with - that is, apply - the subject content in order to learn it.

The committee points out that being able to communicate, interact and participate entails being able to read, write and articulate verbally (NOU, 2015:8, s.2829). Furthermore, for learning tasks to be intellectually challenging, an intellectually challenging environment is needed. In TLT, this corresponds with a learning-centred dialogic approach, which exhibits certain characteristics, such as that instruction - dialogue - has an explorative starting point aimed at gaining new insights (Gravett, 2001, p. 36). Thus, it is essential for the process of

${ }^{5}$ Readers familiar with deliberative theory will recognise Habermas' influence on the concept of dialogue in TLT. 
education to be grounded in intellectually challenging activities. To meet this objective, students are obliged to make active use of, and reason about, the subject content. This, in turn, presupposes that students articulate their understanding both verbally and in writing (Gravett, 2001, p. 22). Creating such an environment demands that students feel that it is safe to try out their perceptions in the community and that it is acceptable for others to challenge these perceptions. In other words, the learning environment should be positive, challenging, respectful and engaging all at the same time. This is because such an environment invites students to take the risk of articulating their thoughts in the classroom and respond to others who articulate their thoughts, while feeling safe at the psychological level (Gravett, 2001, p. 32).

The next point, which is connected to the discussion about intellectually challenging activities and environments, is that there should be clear and explicit expectations from the teacher and students as well as norms for interaction. For dialogical instruction to be realised, it is important for students to be met by clear expectations. This can have a major impact on their willingness and ability to participate in dialogue. Students who are used to having only the teacher deliver information might very well believe that he or she is the only one worth listening to and that other students have nothing to contribute. Thus, they must learn to trust themselves and other students as resources for joint learning (Gravett, 2001, p. 38).

Furthermore, the realisation of an intellectually challenging environment and activity requires the inclusion of diverse perspectives in the dialogue. Good thinking - as well as fruitful dialogue - depends on the presence of alternate explanations and perspectives. Here, there is a clear connection with Mezirow's (1991) concept of critical reflection. An important purpose of dialogical teaching, according to Mezirow, is to present and evaluate the validity of different points of view, drawing on a wide spectrum of arguments and evidence. In this understanding, critical reflection can emerge as a result of dialogue because students gain insights through exploring a question that rattles and informs their understanding. As Barnett (In Kreber, 2012, p. 330) points out, 'true dialogue is about taking the viewpoints of others seriously, and thereby also possibly move into another world held open by others'.

\section{Explorative and creative competence}

The Ludvigsen Committee connects being able to create and explore with creativity, innovation, critical thinking and problem solving. The committee also underlines the importance of 'curiosity, endurance, openness to see things in new ways, and the ability to take initiative' as important aspects of this kind of competence (NOU, $2015: 8$, p. 31). It is said that critical thinking and problem solving can often be seen conjunctively and that students should be able to reason and analyse, identify relevant questions and use relevant strategies to solve complex problems (NOU, 2015:8, p. 33). In the committee's report, however, this kind of competence is largely related 
to the future needs of the labour market rather than competencies for democratic citizenship. We argue that this area of competence bears important implications in relation to education for democracy and citizenship. Our argument is grounded in Dewey's contributions, which is one of the pillars of TLT. In what follows, we illustrate the interconnection between Dewey and TLT and how TLT can contribute towards highlighting the manner in which democratic learning in the classroom might be transformative for the learner.

In the essay 'Creative Democracy - The Task Before Us', John Dewey (1939) discusses democracy as a way of life and a moral ideal expressed in habits and attitudes. According to Bernstein (2000, p. 191), a well-known interpreter of Dewey, democracy is not merely one topic among many for Dewey; almost all his thinking seems to spring from and lead back to, reflections on democracy. To believe in democracy as a moral ideal, Dewey suggests, is to believe that each and every person, under the right conditions, is capable of the social intelligence necessary for the realisation of democracy as a way of life. Relatedly, Bernstein (2000, p. 201) suggests that situated creativity is one of the most important categories of Dewey's thinking. To Dewey, a democratic person is someone who possesses flexible, fallible, experimental and inventive capacities. Creativity is not something limited to certain domains or events; rather, it should manifest in all human experience and mundane practices (Dewey, 1939). So understood, democracy as a moral ideal is closely related to the capabilities that the Ludvigsen Committee relates to explorative and creative competencies, such as creativity, critical thinking and problem solving.

In 'How We Think', Dewey (1997) puts forth a specific and didactically applicable five-step method for problem solving. Apparent in these steps is Dewey's preference for explorative learning (Barrow, 2006, pp. 265-266). The five steps of Dewey's (1997) method entail (1) 'a felt difficulty', (2) 'its location and definition', (3) 'suggestion of possible solution', (4) 'development by reasoning of the bearings of the suggestion' and (5) 'further observation and experiment leading to its acceptance or rejection' (Barrow, 2006, p. 72). As Løvlie (2013, p. 257) highlights, the method resembles an approach typical of the natural sciences. However, Dewey's contributions to the topic illustrate that this is much more than a limited cause-effect relationship. Dewey does not perceive the method as a highly specialised scientific method only appropriate for the natural sciences, but believes that it can be applied as an empirical method in problem solving relating to regular and everyday experience (Løvlie, 2013, p. 257).

As Dewey (1997, p. 72) suggests, the two first steps of the method blend into each other. The level of difficulty that one feels can emerge with such strength that it moves one's thinking directly towards trying to solve the problem or disturb one's thinking in a way that gives it a clear determination and delineation. During instruction, such disturbances can arise from both planned and spontaneous situations. As Illeris (2014, p. 126) notes, students do not experience all education or everything in the curriculum as relevant. Thus, it is important for teachers to be able to discover 
and make use of situations where such challenges arise. However, as Bruner (2001) points out, it would be a mistake to think that understanding is something that comes exclusively from within or is intrinsic to the learner. A difficulty that one feels can be imposed from the outside, through what Mezirow (1991, pp. 13-14) calls 'distorting dilemmas'. Further, various tools may evoke such dilemmas: 'an eye-opening discussion, a book, a poem, a painting or an attempt to understand another culture that challenges one's own assumptions' (Mezirow, 1991, pp. 13-14).

The third step, the suggestion of a possible solution, is essentially about a movement from the specific (what is present) to the abstract (what is absent) (Dewey, 1997, p. 75). Being able to delay the urge to draw a final conclusion, and treat possible solutions simply as possible solutions pending further evidence, is a characteristic of an explorative attitude and good thinking. This, in turn, depends on the presence of alternate explanations - something which underpins the importance of cultivating the capacity to develop alternative solutions. In the words of Bruner (2001, p. 116), 'by giving form and expression to our experience, education can (...) be the most important tool to limit our minds. The guarantee against such limits is a proper appreciation for alternatives'. Closely related to this is the fourth step, development by reasoning the bearings of the suggestion. In essence, development by reasoning is about bringing forth the implications of possible solutions to the problem (Dewey, 1997, p. 75). Dewey (1997, p. 76) suggests that development by reasoning is a key aspect in the process; what seems like a good solution at first glance might lose its appeal when its implications are followed through, whereas a solution that does not seem as promising at first might become increasingly attractive.

The fifth and final step of the process entails further observation and experimentation. The purpose is to accept or discard the solution that one has come up with (Dewey, 1997, p. 72). This process should be understood as duplex. On one hand, the possible solution or idea must be tested against observed facts. However, as Løvlie (2013, p. 260) points out, this is not enough: 'Facts must also be tested against the ideas, which will speak against social and political values - values that themselves might change during the process'. Indeed, to Dewey, science or scientific procedures are not independent of, or contrary to, ethics and values. Rather, science and scientific procedures are embedded in ethics and values (Brinkmann, 2006).

\section{Implications for democratic citizenship education}

The main issue for TLT education is the development of liberality and broadmindedness and for students to acquire a deeper connection with themselves through instrumental, communicative and emancipatory learning. Education for personal and societal development has a starting point in new or strengthened awareness about one's own meaning perspectives and the ability for critical reflection and critique of one's assumptions about oneself and the world. The implications for teaching are 
multitude, starting with understanding the members of the classroom as both co-learners and co-teachers. This suggests that it is not solely the students but also the teacher's frames of reference that are changing in a transforming learning process. A second implication is the emphasis on equal status for the different learning modes, instrumental, communicative and emancipatory learning. The Ludvigsen Committee's suggestion to narrow down the subject content and to give priority to in-depth learning is essential for enabling transformative learning.

A third implication is the strengthening of the connection between the different parts of the curriculum, the vision statement and the purposes of the subjects. Contemporaneously, there are major challenges for teachers when it comes to negotiating the different commitments in the curriculum. Several research contributions suggest that teachers have to give priority to fulfilling the teaching of the competence goals described. Thus, they downgrade communicative and emancipatory learning. A forth implication is that learning understood as transformative can contribute to more democratic and experimental classrooms whereby students and teachers can experience and practice learning to live together and develop common democratic values that are beneficial for strengthening the societal democratic environment. A vibrant democratic classroom and democracy as a way of life demand an understanding and acknowledgement of the importance of transformative learning for developing critical thinking and democratic identities.

\section{Transformative learning theory mediating policy and practice}

Policy represents a way of understanding reality, in this case, the reality of education and its goals and societal scope. The theoretical task is to 'translate' the language of policy to that of praxis. Policy represents political visions of education. Politics and education are more blended and intertwined than ever before, especially through international policy recommendations from organisations like the OECD and IEA; followed by an increased use of tests, both on an international and national level. Theory represents a different kind of understanding of education and can be understood as a tool for fulfilling policy goals without losing sight of education as the deeply existential, transformative, identity project that it is, vital for the lives of students and for society as whole. While politics has always affected pedagogy, it is essential to maintain a balance in allowing pedagogical theory to affect policy instructions. Theory can be used for contextualising pedagogically grounded ethics on what goes on in the classroom. In this article, we have argued that transformative learning theory can be used for translating policy into pedagogy.

\section{Biography}

Janicke Heldal Stray is Associate Professor in Education. Her primary field of research is democracy, citizenship and education.

Emil Satra is research fellow in Education. His primary field of research is citizenship education. 


\section{Teaching for democracy: Transformative learning theory mediating policy and practice}

\section{References}

Andersen, B. \& Biseth, H. (2013). The myth of failed integration: The case of Eastern Oslo. City E Society, 25(1), 5-24. doi:10.1111/ciso.12004

Arthur, J., Davison, J. \& Stow, W. (2000). Social literacy, citizenship education, and the national curriculum. London: Routledge/Falmer.

Barrow, L. H. (2006). A brief history of inquiry: From Dewey to standards. Fournal of Science Teacher Education, 17(3), 265-278.

Berger, J. E. (2012). Citizenship: Utdanning til demokratisk medborgerskap i England. In K. L. Berge \& J. H. Stray (Eds.), Demokratisk medborgerskap $i$ skolen (pp. 59-74). Bergen: Fagbokforlaget.

Bernstein, R.J (2000) Creative democracy, the task still before us. American journal of theology E philosophy 215-228.

Bîrzea, C. (2005). Tool for quality assurance for democraitic citizenship in schools (Katalog nummer 140827). www. unesco.org/education/

Biseth, H. (2014). Må vi snakke om demokrati? (pp. 25-45). Oslo: Universitetsforlaget.

Brinkman, S. (2006). John Dewey: En introduktion. København: Hans Reitzels Forlag.

Bruner, J. (2001) Etter John Dewey, hva så? to In E.L. Dale (ed.): Om utdanning. Klassiske tekster. Oslo: Gyldendal Akademisk.

Cranton, P. \& Taylor, E. W. (2012). Transformative learning theory. Seeking a more unified theory. In E. W. Taylor \& P. Cranton (Eds.), The handbook of transformative learning. Theory, research, and practice (pp. 3-20). San Fransisco: Jossey-Bass.

Crick, B. (1998). Education for citizenship and the teaching of democracy in schools. Final report of the Advisory Group on Citizenship.

Dale, E. L. (2005). Kunnskapsregimer i pedagogikk og utdanningsvitenskap. Oslo: Abstrakt forlag.

Dewey, J. (1939). Creative democracy. The task before us. New York: GP Putnam's Sons.

Dewey, J (1997). How We Think. Mineola, New York: Dover Publications.

Englund, T. (2015). Toward a deliberative curriculum. Nordic fournal of Studies in Educational Policy, 1(1) p. 48-56. doi:10.3402/nstep.v1.26558

Englund, T. (2016). On moral education through deliberative communication. Fournal of Curriculum Studies, 48(1), 58-76. doi:10.1080/00220272.2015.1051119

Eriksen, E. O. (1995). Deliberativ politikk: Demokrati i teori og praksis. Oslo: TANO.

Eriksen, E. O. \& Weigård, J. (1999). Kommunikativ handling og deliberativt demokrati: Fürgen Habermas' teori om politikk og samfunn. Bergen: Fagbokforlaget.

Fjeldstad, D., Lauglo, D. \& Mikkelsen, R. (2010). Demokratisk beredskap: Kortrapport om norske ungdomsskoleelevers prestasjoner og svar på spørsmål $i$ den internasjonale demokratiundersøkelsen: International civic and citizenship education study (ICCS 2009). [Oslo]: Institutt for lærerutdanning og skoleutvikling, Universitetet i Oslo.

Føllesdal, A. (2002, Dec. 06). Rawls og Norge. Morgenbladet, p. 8.

Føllesdal, A. (2003). Innledning til Retteferdighet som rimelighet. In J. Rawls (Ed.), Rettferdighet som rimelighet (Vol. 1, pp. 11-37). Oslo: Pax Forlag.

Gravett, S. (2001). Adult learning. Designing and implementing learning events. A dialogic approach. Pretoria: van Schaik.

Illeris, K. (2014). Transformative Learning and Identity. London and New York: Routledge

Kemp, P. (2005). Verdensborgeren som padagogisk ideal: Pcedagogisk filosofi for det 21. århundrede. København: Hans Reizels Forlag.

Korsgaard, O. (2005). Medborgerskab, identitet og demokratisk dannelse. København: Danmarks Pædagogiske Universitets Forlag.

Kreber, C. (2012) Critical Reflection and Transformativ Learning. In E.W. Taylor and P. Cranton (Eds.): The Handbook of Transformative Learning. San Fransisco: Jossey-Bass.

Kymlicka, W. \& Norman, W. (1995). Return of the citizen: A survey of recent work on citizenship theory. In R. Beiner (Ed.), Theorizing citizenship (pp. 283-322). Albany: State University of New York Press.

Løvlie, L. (2006). Education for deliberative democracy. In I. G. Ze'ev \& K. Roth (Eds.), Critical issues in education in a global world (Vol. 1). New York: Springer.

Løvlie, L. (2013). John Dewey: Danning til demokrati. In I. Straume (Ed.) Danningens filosofihistorie. Oslo: Gyldendal Akademisk.

Meld.St.28. (2016). Fag-fordypning - forståelse: En fornyelse av Kunnskapsløftet. Oslo: Kunnskapsdepartementet. 


\section{Fanicke Heldal Stray and Emil Satra}

Mezirow, J. (1991). Transformative dimensions of adult learning. San Fransisco: Jossey-Bass.

Mezriow, J. (2000). Learning as transformation: Critical perspectives on a theory in progress. San Fransisco: Jossey-Bass.

Mikkelsen, R. (2001). Demokratisk beredskap og engasjement hos 9.-klassinger $i$ Norge og 27 andre land: Civic education study Norge 2001 (82-90904-60-6).

NOU. (2015). Fremtidens skole: fornyelse av fag og kompetanser. Oslo: Kunnskapsdepartementet.

Solhaug, T. \& Børhaug, K. (2012). Skolen i demokratiet - Demokratiet $i$ skolen. Oslo: Universitetsforlaget.

Stokkeland, S. (2016). Holdningsdanning i religionsundervisning. Lererperspektiver på religionsfagets dannelsesaspekt (Master), Det teologiske Menighetsfakultetet, Oslo.

Stray, J. H. (2010). Demokratisk medborgerskap i norsk skole? En kritisk analyse (Ph.d-avhandling), PFI/UiO, Oslo.

Stray, J. H. (2011). Demokrati på timeplanen. Bergen: Fagbokforlaget.

Stray, J. H. (2012). Demokratipedagogikk. In K. L. Berge \& J. H. Stray (Eds.), Demokratisk medborgerskap $i$ skolen (pp. 17-33). Bergen: Fagbokforlaget.

Sætra, E. (2015). Demokratisk medborgerskap i samfunnsfag. Lererperspektiver på demokratiopplaring. (Masteroppgave) ILS/UiO, Oslo

Thuen, H. \& Vaage, S. (2004). Pedagogiske profiler: Norsk utdanningstenkning fra Holberg til Hernes. Oslo: Abstrakt forlag. 